\title{
Foraging Habitat and Chick Diets of Roseate Tern, Sterna dougallii, Breeding on Country Island, Nova Scotia
}

\section{Aire d'alimentation et régime alimentaire des oisillons de la Sterne de Dougall (Sterna dougallii) à l'île Country, Nouvelle-Écosse}

\author{
Jennifer C. Rock, Marty L. Leonard ${ }^{1}$, and Andrew W. Boyne ${ }^{2}$
}

\begin{abstract}
Breeding seabirds are threatened by human activities that affect nesting and foraging habitat. In Canada, one of the seabirds most at risk of extirpation is the Roseate Tern, Sterna dougallii. Although critical nesting habitat has been identified for the Roseate Tern in Canada, its foraging locations and the diet of its chicks are unknown. Therefore, our goal was to determine the foraging locations and diet of chicks of Roseate Tern breeding on Country Island, Nova Scotia, which is one of Canada's two main breeding colonies. In 2003 and 2004, we radio-tracked the Roseate Tern by plane to locate foraging areas and conducted feeding watches to determine the diet of chicks. Roseate Tern foraged approximately $7 \mathrm{~km}$ from the breeding colony over shallow water $<5 \mathrm{~m}$ deep. In both years, sand lance, Ammodytes spp., was the most common prey item delivered to chicks, followed by hake, Urophycis spp. Our results are consistent with previous work at colonies in the northeastern United States, suggesting that throughout its range, this species may be restricted in both habitat use and prey selection. The reliance on a specific habitat type and narrow range of prey species makes the Roseate Tern generally susceptible to habitat perturbations and reductions in the availability of prey.
\end{abstract}

RÉSUMÉ. Les oiseaux de mer sont menacés par les activités humaines qui touchent leur habitat de nidification et leurs aires d'alimentation. Au Canada, la Sterne de Dougall (Sterna dougallii) est l'un des oiseaux de mer les plus menacés de disparaître du pays. Même si son habitat de nidification critique a été identifié, ses sites d'alimentation et le régime alimentaire des oisillons demeurent inconnus. Notre objectif était de déterminer le régime alimentaire des oisillons et les sites d'alimentation de la Sterne de Dougall qui niche à l'île Country, en Nouvelle-Écosse, l'une des deux principales colonies de cette espèce au Canada. En 2003 et 2004, nous avons fait un suivi télémétrique des sternes afin de localiser, par avion, leurs sites d'alimentation, et avons observé le nourrissage des oisillons afin de préciser leur régime alimentaire. Les Sternes de Dougall s'alimentaient à environ $7 \mathrm{~km}$ de la colonie, dans des zones d'eau peu profonde $(<5$ $\mathrm{m})$. Les deux années, les lançons (Ammodytes spp.) étaient la proie la plus souvent rapportée aux oisillons, suivis des merluches (Urophycis spp.). Nos résultats sont en accord avec les travaux antérieurs menés dans des colonies du nord-est des États-Unis, ce qui suggère que, dans l'ensemble de son aire, la Sterne de Dougall pourrait être limitée quant à l'utilisation d'habitats et à la sélection de proies. Le fait que cette espèce dépende d'un habitat spécifique et d'un éventail restreint de proies contribue à sa vulnérabilité face aux perturbations de son habitat et à la diminution de la disponibilité de ses proies.

Key Words: diet of chicks; foraging; foraging habitat; Roseate Tern; sand lance; Sterna dougalii; terns

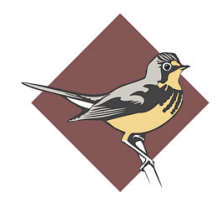




\section{INTRODUCTION}

Worldwide, breeding seabirds are threatened by human activities. On land, for example, logging, farming, and urban development can destroy breeding sites (Brown and Nettleship 1982, Vermeer and Rankin 1982, Furness and Monaghan 1987), and disturbance associated with recreational activities can lead to nest desertion or reduced breeding success (Benoit and Bretagnolle 2002). At sea, foraging birds can be exposed to pollutants (Thompson and Hamer 2000, Burger and Gochfeld 2001), compete with fisheries for prey (Furness and Ainley 1982), and be caught as by-catch in fishing nets (Lewison et al. 2004). These activities have undoubtedly contributed to the large declines that some seabird species have experienced over the last century (LeCorre et al. 2003, Lewison and Crowder 2003, Frederikson et al. 2004).

Ensuring safe breeding opportunities for seabirds thus requires not only the protection of the colony, but also the protection of important foraging habitat (Brown and Nettleship 1982, Croxall et al. 1984, Nettleship 1991). Although the locations of many key seabird colonies are known, generally, little is known little about foraging areas. To date, this represents one of the principal gaps in knowledge that directly affects conservation efforts (Boersma et al. 2001).

In Canada, one of the seabirds most at risk of extirpation is the Roseate Tern, Sterna dougallii (Brown and Nettleship 1982, Environment Canada 2006). The Roseate Tern nesting in Canada belongs to the northeastern North American breeding population that ranges from Nova Scotia to New York (Environment Canada 2006). This breeding population consists of about 4000 pairs that together represent approximately $8 \%$ of the total global population. Roseate Tern was listed as endangered by the U.S. Fish and Wildlife Service in 1987 (Gochfeld et al. 1998) and by the Committee on the Status of Endangered Wildlife in Canada in 1999. Approximately 120 pairs of Roseate Tern nest in Canada and most are concentrated in two colonies in Nova Scotia: the Brothers, supporting approximately two-thirds of the population; and Country Island, supporting the remaining one-third (Leonard et al. 2004).

Roseate Tern can be found nesting in small clusters among other, more abundant tern species (Gochfeld 1983). The northeastern North American breeding population has historically occurred in low numbers (Kirkham and Nettleship 1987, Gochfeld et al. 1998, Nisbet and Spendelow 1999), and specialized foraging behavior is suspected to be a possible explanation for this (Safina 1990, Nisbet and Spendelow 1999).

In breeding colonies in the northeastern United States, Roseate Tern forages over shallow sand shoals and tide rips up to $25 \mathrm{~km}$ from the breeding colony (Safina 1990, Heinemann 1992, Nisbet and Spendelow 1999). The birds also show fidelity to particular foraging sites (Heinemann 1992), sometimes using a single location over several years. Adults at these sites deliver few prey species, predominantly feeding chicks sand lance, Ammodytes spp. (Richards and Schew 1989, Safina et al. 1990, Heinemann 1992). This reliance on a relatively specific habitat type and narrow range of prey species may make the Roseate Tern particularly vulnerable to environmental disturbances (Safina et al. 1990).

This vulnerability underscores the need to identify and protect foraging habitat around Canadian breeding colonies. Critical nesting habitat has been identified for Roseate Tern on its Canadian breeding grounds (Environment Canada 2006); however, it is not clear where the birds forage or what prey species they bring to chicks during the breeding season. Identifying foraging areas and the main prey species is necessary if the Roseate Tern is to be fully protected in Canada.

Foraging behavior and diet can vary in response to local conditions (Schneider and Hunt 1982). Consequently, the results of the studies reported above may not necessarily apply to breeding colonies elsewhere. We conducted a 2 -yr study to locate foraging sites and determine the diets of chicks of the Roseate Tern nesting on Country Island, Nova Scotia, one of Canada's two main breeding colonies.

\section{METHODS}

\section{Study area}

We conducted our study between May and August 2003 and 2004 on Country Island, Guysborough County, Nova Scotia $\left(45^{\circ} 06^{\prime} \mathrm{N}, 61^{\circ} 32^{\prime} \mathrm{W}\right)$. This 19-ha island is situated $5 \mathrm{~km}$ offshore and is surrounded by cobble beach and rocky shoals 
(Whittam and Leonard 1999). Approximately 410 Common Tern, S. hirundo, pairs; 729 Arctic Tern, S. paradisaea, pairs; and 41 Roseate Tern pairs currently breed on Country Island (Toms et al. 2006).

Roseate Tern typically arrives at the breeding colony in May and lay the first eggs in early to midJune. Generally, the Roseate Tern lays 1-2 eggs in nests that are hidden under vegetation, rocks, or driftwood (Gochfeld et al. 1998). Incubation and chick rearing is performed by both parents, with each stage lasting about 3 wk (Gochfeld et al. 1998).

Each year, from the last week of June to the end of July, we systematically searched the tern colony every two days for Roseate Tern. We identified potential nests sites by locating adult birds from blinds. Nests suspected to belong to the Roseate Tern were marked and later confirmed by followup observations of incubating adults made from blinds. We assigned each nest a unique identifying number and marked them with tongue depressors placed within $0.5 \mathrm{~m}$ of the nest cup. We recorded the number of Roseate Tern nests; for each nest, we noted the number of eggs and chicks. Once chicks were 5 days old, we banded them with standard U. S. Fish and Wildlife Service bands. In both years of the study, the Roseate Tern was found at the center and edges of the colony, nesting in small clusters among nesting Arctic Tern and Common Tern.

\section{Radio tags}

During late incubation, we used a wire drop trap to capture one adult from each of five Roseate Tern pairs in 2003 and from each of five pairs in 2004. Each bird was banded with a size-two incoloy U.S. Geological Survey leg band equipped with a radio and battery (model BD-2, Holohil Systems, Carp, Ontario, Canada) that were fused to the band with epoxy. The dimensions of the radio and battery unit were $16 \times 8 \times 3.5 \mathrm{~mm}$ in length $\times$ width $\times$ height, and the antenna was $14 \mathrm{~cm}$ in length. The total mass of the band was $1.1 \mathrm{~g}$ in 2003 and $1.2 \mathrm{~g}$ in 2004, which was equivalent to $<1.2 \%$ of the average bird body mass. The battery life of the radio transmitters was approximately $4 \mathrm{wk}$ in 2003 and $6 \mathrm{wk}$ in 2004. We found no difference in hatching success or chick growth rates in broods with and without a tagged parent (data not shown).

\section{Radio tracking}

We tracked tagged birds using a Cessna 172 floatplane with a Yagi receiving antenna mounted on each wing strut. The antennae were connected to an ATS R2100 receiver (Advanced Telemetry Systems, Isanti, Minnesota, USA). We manipulated reception between the right and left sides of the plane using a left-right switchbox. Throughout all surveys, there was one observer on each side of the plane.

We conducted surveys from an altitude of $300 \mathrm{~m}$ on clear days with calm winds, i.e., $<15$ knots. At this altitude, we could detect signals located 5-7 km away and we could also determine whether a tagged bird was in transit or foraging, which was evident from plunge-diving and surface-picking behaviors. Our methods for tracking birds differed between years; thus, we describe the protocol for each year separately.

To determine the foraging locations of Roseate Tern in 2003, we tracked tagged birds from the breeding colony over a 4-h period between 0900 and 1530 on each of three days between 29 June and 7 July. During this stage of the breeding season, birds were either incubating eggs or rearing young chicks; the hatch date of the first chick of the brood was 1 July \pm 1.1 days (mean \pm standard error). We tracked birds by circling the breeding colony and scanning through the radio frequencies every two seconds. Once we detected a tagged bird leaving the island, we followed it by flying in a zig-zag pattern and used the left-right switchbox to pinpoint the direction of the signal. When we visually located the tagged bird, we circled it to confirm its identity and followed it until it began foraging. We recorded the foraging location coordinates using GPS and by marking the location on a map of the area. Once we recorded the coordinates, we returned to the colony and repeated the procedure.

In 2004, we conducted a 4-h systematic aerial survey between 0800 and 1500 on each of seven days between 7 July and 5 August. During this time, birds were either incubating eggs or rearing chicks; the hatch date of the first chick of the brood was 6 July \pm 2.3 days (mean \pm standard error). The survey area encompassed all waters $<20 \mathrm{~m}$ deep within 20-25 $\mathrm{km}$ of the colony for a total survey area of $330 \mathrm{~km}^{2}$. We selected the boundaries of the survey area based on the results of tracking in 2003, which showed that most birds foraged in waters $<10 \mathrm{~m}$ deep, and 
previous research from other locations, which found that the Roseate Tern foraged up to $25 \mathrm{~km}$ from the breeding colony (Duffy 1986, Heinemann 1992, Nisbet and Spendelow 1999).

We divided the survey area into nine east-west transects that ranged in length from 20 to $33 \mathrm{~km}$, each separated by 1 ' latitude intervals. Surveys were conducted by flying along each transect at approximately $145 \mathrm{~km} / \mathrm{h}$, beginning with the eastern end of the closest inshore transect or the furthest offshore transect on alternate surveys, and scanning through the tag frequencies every two seconds. Once a signal was detected, we followed the protocol described above for 2003 and then resumed the transect survey.

\section{Feeding watches}

We conducted 2-h feeding watches of 21 Roseate Tern broods, i.e., 7 broods in 2003 and 14 broods in 2004, from blinds located 5-10 m away. We carried out feeding watches at each nest beginning when chicks were 2 days old and continuing daily until fledging or disappearance. We balanced watches for time of day by spreading them equally across two watch periods: morning, 0500-1100; or afternoon, 1500-2100. Observations were made only during dry weather, using binoculars. Some nests were difficult to follow because parents moved their chicks away from the original nest site and sometimes relocated chicks to areas where we could no longer monitor prey deliveries from a blind. We do not present feeding rates because our view of the chicks was often obstructed by rocks or vegetation, and it was difficult to determine whether the chicks consumed each prey item.

Where possible, we recorded the species of prey delivered to young on each feeding trip. Fish were identified to genus based on descriptions provided by previous monitoring of tern diets on Country Island (Toms et al. 2006) and comparisons with preserved collections and prey that had been dropped in the colony. When prey items could not be identified, they were classified as unknown.

\section{Analyses}

We plotted every point where a tagged bird was detected in 2003 and 2004 onto a map of the area using the GIS software MapInfo Professional version 6.5 (MapInfo Corporation 2004) and Canadian Hydrographic Service charts 4233 Cape Canso to Country Island and 4234 Country Island to Barren Island (scale of 1:60,000). We estimated the water depth at the foraging locations by plotting 5- and 10-m bathymetric contours onto the same map with the foraging locations, and measured the shortest distance between each foraging location and the colony or the closest point on the mainland using straight-line distances.

To determine whether foraging birds were concentrated in particular areas, we used the foraging location points to create kernel density plots (Wood et al. 2000) using ArcView desktop GIS (Environmental Systems Research Institute, Redlands, California, USA) and Animal Movement extension for ArcView 3.2 (Hooge et al. 1999). We created density plots that encompassed 50,75 , and $95 \%$ of the foraging locations for all tagged birds. There were few repeat observations of individual birds, so we did not examine whether individual birds showed foraging site fidelity.

To determine the diversity of prey species fed to Roseate Tern chicks, we calculated the ShannonWeiner index of diversity, $H^{\prime}$ (Zar 1999),

$$
\left(H^{\prime}\right)=-\sum_{i=1}^{s} p_{i} \log _{e} p_{i}
$$

where $p_{\mathrm{i}}$ is the proportion of the $i$ th species in the diet and $s$ is the total number of species in the diet. $H^{\prime}=0$ indicates no diversity and $H^{\prime}=1$ indicates high diversity. We calculated $H^{\prime}$ ' separately for each year.

\section{RESULTS}

We recorded 32 foraging locations from nine tagged individuals of Roseate Tern across the $2 \mathrm{yr}$ of the study, with $3.6 \pm 0.3$ observations per bird (mean \pm standard error, range of 2-6; Fig. 1). The 10th bird was detected at the colony, but was not located while foraging. Roseate Terns foraged $6.9 \pm 1.5 \mathrm{~km}$ (mean \pm standard error, range of $1.1-23.9 \mathrm{~km}$ ) from the 
Fig. 1. Foraging locations of nine radio-tagged Roseate Terns in 2003 and 2004 in relation to the 5- and 20-m depth contours surrounding Country Island, Nova Scotia, Canada. The inset in the top right corner shows the location of Country Island on the eastern coast of Canadia.

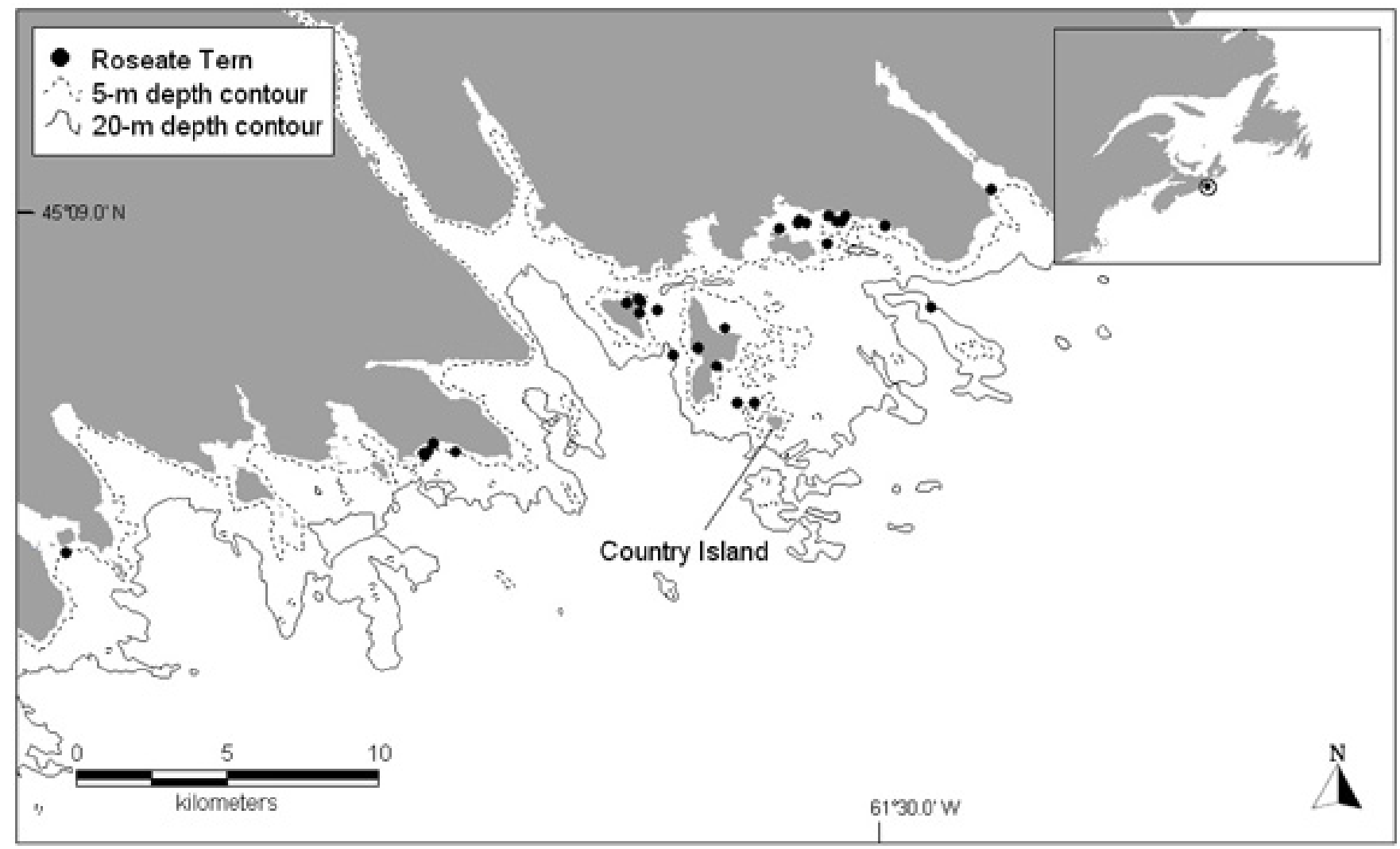

breeding colony, within $1.3 \pm 0.4 \mathrm{~km}$ (range of $0.1-$ $4.1 \mathrm{~km}$ ) of the mainland, and within $0.3 \pm 0.1 \mathrm{~km}$ (range of $0.1-1.3 \mathrm{~km}$ ) of the closest point of land, including islands. The greatest concentration, i.e., $50 \%$, of foraging locations was located near shorelines along both the mainland and islands near the breeding colony (Fig. 2). Of the 32 foraging locations, 29 , i.e., $90 \%$, were in water $<5$ m deep (Fig. 1). Based on the $330 \mathrm{~km}^{2}$ that we surveyed in 2004 , this water depth represents $12 \%$ of the total survey area. The remaining three locations were in water between 5 and 20 m deep.

In total, 234 food deliveries were observed over the 2 yr of the study. Sand lance was the most common prey item delivered to chicks, followed by hake, Urophycis spp. (Table 1). Together, these species accounted for 82 and $72 \%$ of identified prey in 2003 and 2004, respectively (Table 1). The remaining identified prey species included herring, Clupea spp., in 2003 and cod, Gadus spp., in 2004 (Table $1)$. The diversity, $H^{\prime}$, of prey species fed to Roseate Tern chicks across the $2 \mathrm{yr}$ of the study was 0.24 \pm 0.06 prey species (mean \pm standard error) for 21 nests in 2003 and 234 nests in 2004.

\section{DISCUSSION}

The Roseate Tern at Country Island foraged an average of $7 \mathrm{~km}$ from the breeding colony in shallow water close to land. These results are consistent with those of earlier studies of colonies in the northeastern United States showing that the Roseate Tern forages from $300 \mathrm{~m}$ to $25 \mathrm{~km}$ from breeding 
Fig. 2. Density plots from kernel estimations of foraging locations for radio-tagged Roseate Tern nesting on Country Island, Nova Scotia, Canada, in 2003 and 2004. Contours indicate 50, 75, and 95\% density locations.

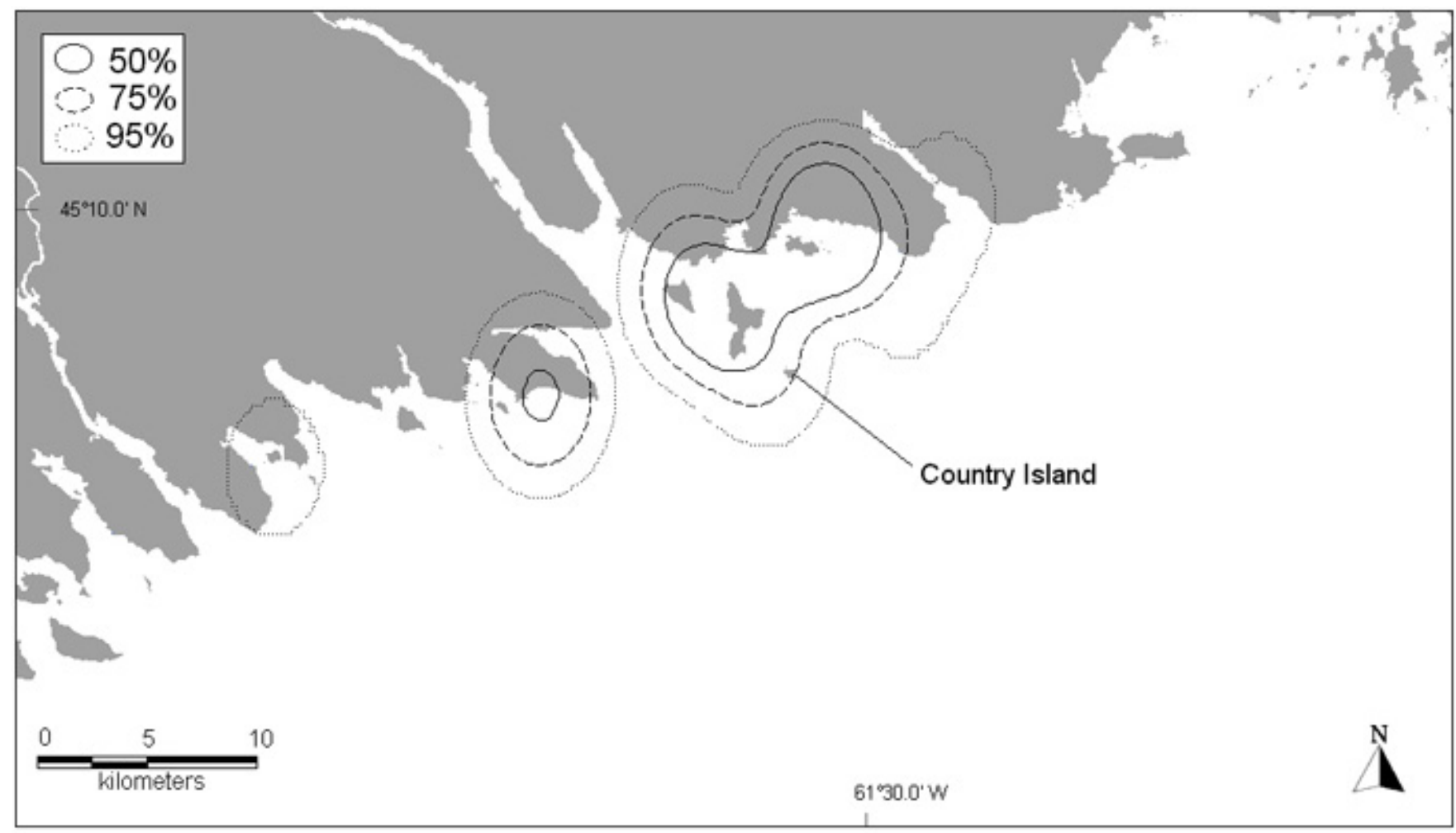

colonies (Duffy 1986, Heinemann 1992, Nisbet and Spendelow 1999) and in shallow water, often < 1 $\mathrm{km}$ from shore (Safina 1990, Heinemann 1992). In contrast, Roseate Tern in tropical and subtropical colonies forages in relatively deep water in association with predatory fish (Hulsman 1989, Shealer 1996, Ramos 2000). Therefore, the Roseate Tern at Country Island foraged in similar habitats to individuals nesting in the northeastern United States, and this behaviour may in fact be characteristic of the entire breeding population. To protect critical habitat for the Roseate Tern at Country Island, the protection of areas of shallow water within $10 \mathrm{~km}$ of the colony is required, especially at sites $<5 \mathrm{~m}$ deep.

The single most important prey item for Roseate Tern chicks at Country Island was sand lance. Again, this result agrees with those of studies from colonies in the United States, in which the diets of chicks were also dominated by sand lance (Richards and Schew 1989, Safina et al. 1990, Heinemann 1992, Nisbet and Spendelow 1999) up to and including the post-fledging period (Shealer and Kress 1994, Watson and Hatch 1999). At colonies located outside of the United States, studies have shown that the diets of chicks are also dominated by a few prey species (Randall and Randall 1978, Shealer and Kress 1994, Shealer and Burger 1995, Shealer 1998, Ramos 2000); however, the prey species vary depending on the colony location. The Roseate Tern at Country Island shares a similar reliance on sand lance as do individuals nesting at other sites in the northeastern United States, indicating that this may be characteristic of this breeding population.

Roseate Tern at Country Island fed chicks only three species of identifiable prey in each year of the study, which was reflected by the relatively low diversity 
Table 1. Percentage of each prey type in the diet of Roseate Tern chicks on Country Island, Nova Scotia, Canada, in 2003 ( $\mathrm{n}=7$ broods) and 2004 ( $\mathrm{n}=14$ broods).

\begin{tabular}{lrr}
\hline \hline Prey type & 2003 & 2004 \\
\hline Sand lance (Ammodytes spp.) & 48.7 & 64.8 \\
Hake (Urophycis spp.) & 33.9 & 7.3 \\
Herring (Clupea spp.) & 6.4 & 0.0 \\
Cod (Gadus spp.) & 0.0 & 3.7 \\
Unknown & 11.0 & 24.2
\end{tabular}

index of $0.24 \pm 0.06$. The diets of chicks of the nesting Arctic Tern and Common Tern were also dominated by hake $(56.1 \pm 7.6 \%)$ and sand lance $(23.5 \pm 5.7 \%)$; however, the diet diversity of these tern species was high, at $0.35 \pm 0.06$ for Arctic Tern and $0.38 \pm 0.05$ for Common Tern, and consisted of eight to ten prey types (Rock 2005). Similarly, other studies have shown that the diet diversity of Roseate Tern chicks is low compared to that of co-nesting Sandwich Tern (Shealer 1998) and Common Tern (Safina et al. 1990). These results from a number of sites show that the Roseate Tern apparently relys on a relatively narrow range of prey for provisioning chicks compared to co-nesting tern species.

Our results and those of previous work on other populations of Roseate Tern in the northeastern United States support the idea that this breeding population is restricted in its habitat use and prey selection. The reliance on a specific habitat type and narrow range of prey species may have implications for the conservation of this endangered species. For instance, species with specialized diets are less able to switch to alternate prey should their preferred food resources decline (Furness and Monaghan 1987). This point is well illustrated by a population of Roseate Tern breeding in Puerto Rico, where, as elsewhere, they feed their chicks a narrow range of prey items. When the preferred prey in this area apparently declined, the Roseate Tern failed to deliver alternative prey, which in turn resulted in reduced breeding and reproductive success (Shealer 1996, 1998). The dependence on a narrow range of resources or specialized foraging behavior may also limit the distribution of specialist species such as the Roseate Tern (Safina 1990). Species that exploit a narrow range of resources are more prone to decline than are species that occupy a broader and more flexible niche (Pimm and Pimm 1982). Indeed, there is some evidence that the availability of foraging habitat may limit the distribution of breeding colonies in the northeastern United States (Nisbet and Spendelow 1999), making the population more concentrated and thus more vulnerable to chance events.

The specializations described above make the Roseate Tern generally susceptible to habitat perturbations throughout its range. However, individual breeding colonies of the Roseate Tern also face specific threats, and the colony on Country Island is no exception. Increasing industrialization in the Country Harbour area is raising concerns for Roseate Tern conservation in Canada. Particular attention should be given to developments and activities that will potentially disturb important fish habitat or foraging birds; in addition, the possibility of cumulative effects from industry should be considered. Although our telemetry results are limited by small sample sizes, we have established baseline information on the foraging habitat and diet of chicks of the Roseate Tern in Canada, which had not been described previously. 
Responses to this article can be read online at: http://www.ace-eco.org/vol2/iss1/art4/responses/

\section{Acknowledgments:}

Many thanks to Tartan Air, K. Dillon, S. Pullen, I. Desjardins, J. McKnight and J. Beukens for assistance in the field. S. Lewis provided GIS assistance and $S$. Chisholm provided expertise on Country Island. G. Davoren, A. Horn, I. MacLaren, $H$. Whitehead and two anonymous reviewers provided comments on earlier versions of the manuscript. This work was funded by the Canadian Wildlife Service, Environment Canada's Interdepartmental Recovery Fund, World Wildlife's Endangered Species Recovery Fund and Dalhousie University. Logistical support was provided by the Canadian Coast Guard, Nova Scotia Department of Natural Resources and the Manthorne family.

\section{LITERATURE CITED}

Benoit, M. P., and V. Bretagnolle. 2002. Seabirds of the southern Lagoon of New Caledonia, distribution, abundance and threats. Waterbirds 25:202-213.

Boersma, P. D., J. A. Clark, and N. Hillgarth. 2001. Seabird conservation. Pages 559-579 in E. A. Schreiber and J. Burger, editors. Biology of marine birds. CRC press, New York, New York, USA.

Brown, R. G. B., and D. N. Nettleship. 1982. The seabirds of northeastern North America: their present status and conservation requirements. Pages 85-100 in J. P. Croxall, P. G. H. Evands, and R. W. Schreiber, editors. Status and conservation of the world's seabirds. Technical publication 2.

International Council for Bird Preservation, Cambridge, UK.

Burger, J., and M. Gochfeld. 2001. Effects of chemicals and pollution on seabirds. Pages 485-526 in E. A. Schreiber and J. Burger, editors. Biology of marine birds. CRC Press, New York, New York, USA.

Duffy, D. C. 1986. Foraging at patches: interactions between common and roseate terns. Ornis Scandinavica 17:47-52.
Environment Canada. 2006. Recovery strategy for the Roseate Tern (Sterna dougallii) in Canada. Species at Risk Act Recovery Strategy Series, Environment Canada, Ottawa, Canada.

Frederikson, M., S. Wanless, M. P. Harris, P. Rothery, and L. J. Wilson. 2004. The role of industrial fisheries and oceanographic change in the decline of North Sea black-legged kittiwakes. Journal of Applied Ecology 41:1129-1139.

Furness, R. W., and D. G. Ainley. 1982. Threats to seabird populations presented by commercial fisheries. Pages 701-708 in J. P. Croxall, P. G. H. Evands, and R. W. Schreiber, editors. Status and conservation of the world's seabirds. Technical publication 2. International Council for Bird Preservation, Cambridge, UK.

Furness, R. W., and P. Monaghan. 1987. Seabird ecology. Chapman Hall, New York, New York, USA.

Gochfeld, M. 1983. The Roseate Tern: world distribution and status of a threatened species. Biological Conservation 103:103-121.

Gochfeld, M., J. Burger, and I. C. T. Nisbet. 1998. Roseate Tern (Sterna dougallii) in A. Poole and F. Gill, editors. The birds of North America. Number 370. Academy of Natural Sciences, Philadelphia, Pennsylvania, USA, and American Ornithologists' Union, Washington, D.C., USA. [online] URL: htt p://bna/birds.cornell.edu/BNA/.

Heinemann, D. 1992. Foraging ecology of Roseate Terns breeding on Bird Island, Buzzards Bay, Massachusetts. Unpublished report to the U.S. Fish and Wildlife Service, Newton Corner, Massachusetts, USA.

Hooge, P. N., W. Eichenlaub, and E. Solomon. 1999. The animal movement program. U.S. Geological Survey, Alaska Biological Science Center, Anchorage, Alaska, USA.

Hulsman, K. 1989. The structure of seabird communities: an example from Australian waters. Pages 59-91 in J. Burger, editor. Seabirds and other marine vertebrates: competition, predation and other interactions. Columbia University Press, New York, New York, USA.

Kirkam, I. R., and D. N. Nettleship. 1987. Status of the Roseate Tern in Canada. Journal of Field 
Ornithology 58:505-515.

LeCorre, M., T. Ghestemme, M. Slamolard, and F. Couzi. 2003. Rescue of the Mascarene Petrel, a critically endangered seabird of Reunion Island, Indian Ocean. Condor 105:387-391.

Leonard, M., A. Boyne, and S. Boates. 2004. Status and management of Roseate Terns (Sterna dougallii) in Nova Scotia. Proceedings of the Nova Scotia Institute of Science 42:253-263.

Lewison, R. L., and L. B. Crowder. 2003. Estimating fishery bycatch and effects on a vulnerable seabird population. Ecological Applications 13:743-753.

Lewison, R. L., L. B. Crowder, A. J. Read, and S. A. Freeman. 2004. Understanding impacts of fisheries bycatch on marine megafauna. Trends in Ecology and Evolution 19:598-604.

MapInfo Corporation. 2004. MapInfo professional version 6.5. Troy, New York, USA.

Nettleship, D. N. 1991. Seabird management and future research. Colonial Waterbirds 14:77-84.

Nisbet, I. C. T., and J. A. Spendelow. 1999. Contribution of research to management and recovery of the Roseate Tern: review of a twelveyear project. Waterbirds 22:239-252.

Pimm, S. L., and J. W. Pimm. 1982. Resource use, competition, and resource availability in Hawaiian Honeycreepers. Ecology 63:1468-1480.

Ramos, J. A. 2000. Characteristics of foraging habitats and chick food provisioning by tropical Roseate Terns. Condor 102: 795-803.

Randall, R. M., and B. M. Randall. 1978. Diet of Roseate Tern during the breeding season at St. Croix Island, Algoa Bay. Cormorant 5:4-10.

Richards, S. W., and W. A. Schew. 1989. Species composition of food brought to Roseate Tern chicks on Falkner Island, Connecticut in summer 1984. Connecticut Warbler IX:1-5.

Rock, J. C. 2005. Foraging habitat and chick diets of Roseate Terns and co-nesting Common andArctic Terns. Dissertation. Dalhousie University, Halifax, Nova Scotia, Canada.
Safina, C. 1990. Foraging habitat partitioning in Roseate and Common Terns. Auk 107:351-358.

Safina, C., R. H. Wagner, D. A. Witting, and K. J. Smith. 1990. Prey delivered to Roseate and Common Tern chicks, composition and temporal variability. Journal of Field Ornithology 61:331-338.

Schneider, D., and G. L. Hunt. 1982. A comparison of seabird diets and foraging distribution around the Pribilof Islands, Alaska. Pages 86-95 in D. N. Nettleship, G. A. Sanger, and P. F. Springer, editors. Marine birds: their feeding ecology and commercial fisheries relationships. Proceedings of the Pacific Seabird Group Symposium. (Seattle, Washington, 1982). Special publication of the Canadian Wildlife Service, Ottawa, Canada.

Shealer, D. A. 1996. Foraging habitat use and profitability in tropical Roseate Terns and Sandwich Terns. Auk 113:209-217.

Shealer, D. A. 1998. Differences in diet and chick provisioning between adult Roseate and Sandwich Terns in Puerto Rico. Condor 100:131-140.

Shealer, D. A., and J. Burger. 1995. Comparative foraging success between adult and one-year-old Roseate and Sandwich Terns. Colonial Waterbirds 18:93-99.

Shealer, D. A., and S. W. Kress. 1994. Postbreeding movements and prey selection of Roseate Terns at Stratton Island, Maine. Journal of Field Ornithology 65:349-362.

Thompson, D. R., and K. C. Hamer. 2000. Stress in seabirds: causes, consequences and diagnostic value. Journal of Aquatic Ecosystem Stress Recovery 7:91-110.

Toms, B., S. Baillie, A. Boyne, and J. McKnight. 2006. Country Island tern restoration project annual report 2004-Year 7. Unpublished report to the Canadian Wildlife Service, Dartmouth, Nova Scotia, Canada.

Vermeer, K., and L. Rankin. 1982. Influence of habitat destruction and disturbance on nesting seabirds. Pages 723-736 in J. P. Croxall, P. G. H. Evands, and R. W. Schreiber, editors. Status and conservation of the world's seabirds. Technical publication 2. International Council for Bird preservation, Cambridge, UK. 
Watson, M. J., and J. J. Hatch. 1999. Differences in foraging performance between juvenile and adult Roseate Terns at a pre-migratory staging area. Waterbirds 22:463-465.

Whittam, R. M., and M. L. Leonard. 1999. Predation and breeding success in roseate terns (Sterna dougallii). Canadian Journal of Zoology 77:851-856.

Wood, A. G., B. Naef-Daenzer, P. A. Prince, and J. P. Croxall. 2000. Quantifying habitat use in satellite-tracked pelagic seabirds: application of kernel estimation to albatross locations. Journal of Avian Biology 31:278-286.

Zar, J. H. 1999. Biostatistical analysis. Fourth Edition. Prentice Hall, Upper Saddle River, New Jersey, USA. 